\title{
Urban Climate Change Governance within Centralised Governments: a Case Study of Giza, Egypt
}

\author{
Eissa Yara ${ }^{1}$ (D Khalil Heba Allah Essam E. ${ }^{1}$ (D)
}

Accepted: 27 August 2021 /Published online: 15 September 2021

(C) The Author(s), under exclusive licence to Springer Nature B.V. 2021

\begin{abstract}
Urban climate governance on the subnational and local government levels requires multilevel governance and local autonomy. Within centralised governments, climate action becomes challenging. Moreover, in developing countries, development needs are usually prioritised, while climate action is viewed as an unaffordable luxury. In a centralised, middle-income country like Egypt, climate action is a challenge for all government levels. This research investigates the current state and the prospect of urban climate change governance on the subnational level in Egypt. A twofold methodology is used. First, through desk research, a comprehensive list of urban climate governance enabling factors was extracted. The list was used to assess the practices of 3 international case studies (Delhi, Durban, and Amman) and then refined and used to assess the first subnational level climate change strategy in Egypt. Second, semi-structured interviews were conducted with a few selected experts working on climate change and urban policies in Egypt. Two sets of recommendations were formulated to expedite urban climate change governance in Egypt, especially on the subnational and local levels. While the research focuses on Egypt, the methodology and recommendations could be adopted and adapted by local governments functioning within centralised systems.
\end{abstract}

Keywords Climate change adaptation - Climate governance · Urban governance · Local government $\cdot$ Centralised government

Eissa Yara

eissayara@gmail.com

Heba Allah Essam E. Khalil

hebakhalil@eng.cu.edu.eg

1 Department of Architecture, Faculty of Engineering, Cairo University, 1 Gamaa Street, Giza 12613, Egypt 


\section{Introduction}

Cities and their inhabitants are the most vulnerable to climate change impacts due to their characteristics as immobile, socio-economic hubs that shelter the majority of the world's human population (UN-Habitat, 2017). Given the central role that local governments play in the urban sectors most affected by climate change, including health, infrastructure, and emergency services (Satterthwaite, 2008), they should lead their local adaptation planning and implementation beyond provision of urban services (Johnson et al., 2015; van der Heijden, 2019). Despite the efforts national governments are putting to address climate change, many cities are still piloting and experimenting with governance arrangements, technologies, and social processes to address the issue (Anguelovski \& Carmin, 2011; Bulkeley, 2010; Gordon, 2018; Heinrichs et al., 2013). Even with the success of a few frontrunners, reaching a formula for successful climate governance is still beyond reach, especially in fast urbanising contexts (van der Heijden, 2017, 2018).

A country's governance framework plays a key role in the efficiency of its adaptation efforts. Overall, there is a need for a governance system, where national, regional, and local decision-making centres collaborate (CIESIN). Therefore, multilevel governance is considered an overarching prerequisite in all urban governance processes (UN-Habitat; Croese et al., 2021), including climate change adaptation planning and implementation. Moreover, multilevel governance is required nowadays since most local governments or their departments seldom have the needed resources, power, and/or governance structure to carry out their responsibilities effectively and govern their constituencies in response to public policy challenges (UN-Habitat; Croese et al., 2021; van der Heijden, 2019).

When it comes to adaptation, each city's experience is unique to its context due to the geographic heterogeneity of climate change. Moreover, a city's political, governmental, and socio-cultural characteristics add to the uniqueness of its response ( $\mathrm{Tu}, 2018$ ). Consequently, research on urban climate change adaptation in cities has a case-by-case nature, and a global governance solution does not exist (RomeroLankao et al. 2018a, b). However, several scholars have attempted to identify factors that define and explain adaptation response and affect and drive local adaptation action and climate response across the globe through analysing existing efforts.

The MIT-ICLEI Urban Climate Change Governance Survey (UCGS) (Aylett, 2014) gives significant insights into the local practice of climate change action based on the experience of 350 ICLEI cities. Alexander Aylett's, 2015 adaptationfocused analysis of the UCGS highlights the different institutional structures utilised by different cities, different tactics for mainstreaming climate change into local government processes, and major challenges to local climate change action (Aylett, 2015). In the Global South, acting on climate change becomes more complex with pressing development needs, limited resources, and in many cases the lack of local autonomy (Croese et al., 2021). In addition, the variation in governance structures across the globe and especially within the Global South challenges the ability to replicate structures and solutions (Croese et al., 2021). Urban climate governance requiring multilevel governance becomes even more challenging within centralised 
governments, where local action is hampered by limited power and jurisdictions of the local level governments (Romero-Lankao et al. 2018a, b; van der Heijden, 2019). Additionally, addressing urban climate governance within megacities of the Global South exhibits an additional level of complexity, where different administrative units comprising the megacity have varied capacities, needs, and contested power (van der Heijden et al., 2019) working under limited coordination capacities across the metropolitan area. Within such complexity, this paper investigates the status quo and prospects of urban climate governance on the local level within a megacity of the Global South. The paper focuses on Egypt and uses Giza Governorate, a sublevel of the Greater Cairo Region (GCR), as a case study. Through analysing the formulated climate change strategy and the current governance challenges, the paper aims to investigate the current state and the prospect of urban climate change governance on the subnational level in Egypt.

\section{Urban Climate Change Governance Enabling Factors}

In order to establish urban climate change governance within the local government, first the basic requirements for urban governance must be met. According to the analysis of literature on urban governance and urban climate change governance (Satterthwaite, 2008; Romero-Lankao et al. 2018a, b; Aylett, 2014; Aylett, 2015; UN-Habitat; UN-Habitat, 2018; Betsill \& Bulkeley, 2007; Yohe, 2001) (Tompkins \& Adger, 2005; Carmin et al. 2012; Metropolis 2015a, 2015b; Klein et al., 2005; Rosenzweig, et al., 2018), enabling factors were extracted and then integrated to form a comprehensive list. Appendix Table 5 encompasses the analysed literature. With a focus on adaptation on the local government level, the list consists of 16 enabling factors, categorised into 4 categories presented in Table 1. In addition to these themed factors, there are 3 overarching enabling factors that should be initiated by the national government, which are:

1. Multilevel governance that is based on proper decentralisation policies and welldefined spheres of government, which ensures subsidiarity, a sufficient degree of autonomy, and good public financial management systems (UN-Habitat; Croese et al., 2021)

2. Holistic sustainability that considers ecology, politics, economy, and culture (UNHabitat, 2018)

3. A legal framework that enables the effective implementation of city-level adaptation (Romero-Lankao et al., 2018a, b)

Interestingly, when studying these enabling factors within 3 case studies of the Global South, the reality is different. The authors investigated Delhi, India (Aggarwal, 2013; Heinrichs et al., 2013; Hughes, 2013; ICLEI South Asia, 2014; Sheikh \& Banda, 2015; Soni, 2014); Durban, South Africa (Sutcliffe \& Bannister, 2015; Roberts \& O’Donoghue, 2013; Environmental Planning \& Climate Protection 
Table 1 The 16 urban climate change governance enabling factors

\begin{tabular}{|c|c|}
\hline Themes & Enabling Factors \\
\hline \multirow[t]{7}{*}{ 1. Governance Framework } & $\begin{array}{l}\text { 1.1 Adequate cooperation and communication between and within all gov- } \\
\text { ernment levels }\end{array}$ \\
\hline & $\begin{array}{l}\text { 1.2 Political leadership and commitment to address climate change impacts } \\
\text { on all levels }\end{array}$ \\
\hline & 1.3 Long-term legal and regulatory changes to support political leadership \\
\hline & $\begin{array}{l}\text { 1.4 Long-term goals and a climate change adaptation action plan that tran- } \\
\text { scend electoral cycles, e.g. through incorporating "no regrets" measures" }\end{array}$ \\
\hline & $\begin{array}{l}\text { 1.5 An institutional framework that gives importance to climate change plan- } \\
\text { ning teams/focal point }\end{array}$ \\
\hline & $\begin{array}{l}\text { 1.6 Synergies and co-benefits between adaptation goals and development } \\
\text { needs }\end{array}$ \\
\hline & $\begin{array}{l}\text { 1.7 Climate change adaptation mainstreaming into the local government's } \\
\text { climate sensitive areas }\end{array}$ \\
\hline \multirow[t]{2}{*}{ 2. Resources } & $\begin{array}{l}\text { 2.1 The provision of technical, technological, and financial support from } \\
\text { higher-level entities }\end{array}$ \\
\hline & $\begin{array}{l}\text { 2.2 Adequate local capacities for climate change adaptation planning and } \\
\text { knowledge that is based on a clear understanding of current adaptive } \\
\text { capacities }\end{array}$ \\
\hline \multirow[t]{2}{*}{ 3. Inclusive cooperation } & $\begin{array}{l}\text { 3.1 Inclusion of, cooperation with and adequate communication between all } \\
\text { relevant stakeholders, including private sector, academia, and NGOs }\end{array}$ \\
\hline & $\begin{array}{l}\text { 3.2 Inclusive and efficient mechanisms of public participation that leave no } \\
\text { one behind }\end{array}$ \\
\hline \multirow[t]{5}{*}{ 4. Knowledge } & $\begin{array}{l}\text { 4.1 A clear understanding of existing climate change vulnerabilities of socie- } \\
\text { ties and ecosystems }\end{array}$ \\
\hline & $\begin{array}{l}\text { 4.2 A clear understanding of the socio-economic costs of climate change } \\
\text { adaptation }\end{array}$ \\
\hline & $\begin{array}{l}\text { 4.3 Access to relevant information on climate change impacts and adapta- } \\
\text { tion/mitigation measures }\end{array}$ \\
\hline & $\begin{array}{l}\text { 4.4 Local knowledge and expertise of local climate change impacts within } \\
\text { local government }\end{array}$ \\
\hline & $\begin{array}{l}\text { 4.5 Awareness raising activities to raise the social acceptance of the need for } \\
\text { adaptation }\end{array}$ \\
\hline
\end{tabular}

"These measures follow the "No Regrets" Charter developed by Metropolis in 2015 (Metropolis 2015a, 2015b).

Department and Energy Office, 2014; Leck \& Simon, 2018; Chu et al., 2017; Environmental Planning \& Climate Protection Department, 2016; eThekwini Municipality, 2017; Roberts, 2018); and Amman, Jordan (Greater Amman Municipality, 2017; Greater Amman Municipality, 2019; Al-Zu'bi, 2017; Hayward, 2019). While the results of the case studies' analyses stress the necessity of some of these enabling factors, they show that not all of them are essential for initiating climate action, but all are necessary for climate action continuity. 


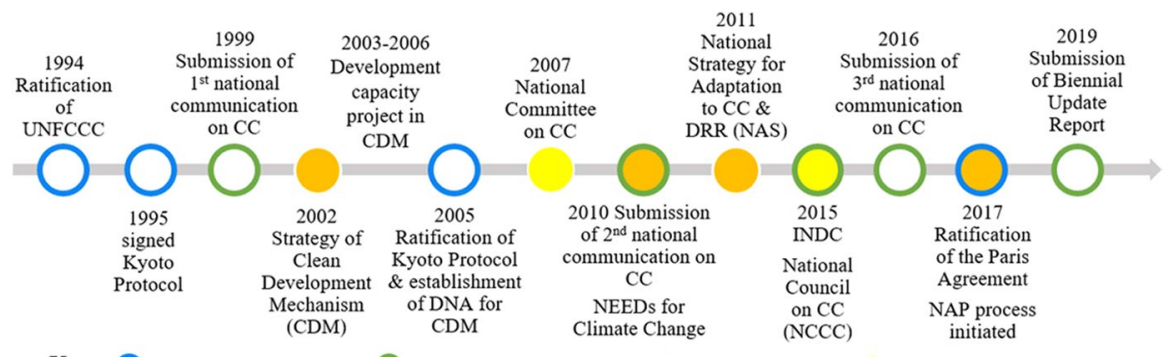

Key: International Commitments 1 International Communications National Documents National Steering Mechanisms

Fig. 1 Egypt's climate change efforts (Ministry of Planning, Monitoring and Administrative Reform, 2018; NAP-GSP, 2018)

\section{Climate Change and Government Structures in Egypt}

\section{Urban Climate Change Governance Within the Egyptian Context}

The Egyptian government, represented by the Ministry of Environment (MOE) and its operational arm the Egyptian Environmental Affairs Agency (EEAA), is keen on facing the threat of climate change mainly through raising the country's adaptive capacity through different adaptation measures in its climate-sensitive sectors and areas. Internationally, Egypt is committed to the international climate governance regime. Figure 1 illustrates a timeline of Egypt's national climate change efforts thus far (Ministry of Planning, Monitoring \& Administrative Reform, 2018). Regarding policies and strategies, Egypt has published its National Strategy for Adaptation to Climate Change and Disaster Risk Reduction (NAS) in 2011 (IDSC, 2011). This strategy lays the foundation for the ongoing National Adaptation Plan (NAP) process, which started in 2017 with the support of the United Nations Development Programme (UNDP) (NAP-GSP, 2018).

\section{Introduction to Giza Governorate: a Subnational Level of Government}

Giza Governorate consists of a variety of functions and land uses. Its total area is $38,157 \mathrm{Km}^{2}$ and is located mostly on the west banks of the Nile River extending into the Western desert. Giza Governorate is divided into 10 Marakez (each with its own capital city and rural units) and 3 cities (Giza city, the governorate's capital, and two desert cities). Giza city consists of 9 districts and is part of the GCR, which is the largest metropolitan area in Egypt. The governorate's area is $61 \%$ urban and $39 \%$ rural, with a total population of 8.6 million, as of October 2017. The governorate consists of different sectors including industry, tourism, and agriculture (Giza Governorate).

Giza Governorate is a subnational level of government that functions within Egypt's central government system, where most fiscal and executive decisions are taken at the national level. The Law of Local Administration number 43 of 1979 and its amendments set the guidelines for the country's administrative structure 
on the local level regarding authorities, hierarchy, and functions. Giza is one of 27 governorates, each led by a governor appointed by the president through a presidential decree (Abdulrahman, 2016). The Ministry of Local Development (MOLD) is responsible for the coordination between the central government and the governorates, and between the governorates. The MOLD also ensures that governorates' activities correspond with national policies and plans. Furthermore, all 27 governors are members of the "Council of Governors", headed by the Prime Minister and joined by the minister of local development (UNDESA, 2004). The power of governorates has remained weak and controlled by the central government concerning budget allocation and staff appointment (UN-HABITAT, 2016). Furthermore, the local system applied in Egypt is not of governance but of administration, which reflects the national government's highly centralised system (Tadamun, 2013; UNDESA, 2004). The governorates' budgetary is centrally managed and allocated by the MOLD (Abdulrahman, 2016). Although Giza Governorate is a subnational level of government, it is the lowest government level that has formulated a climate change strategy in Egypt so far. Moreover, lower levels of government in Egypt do not have sufficient mandate or political and financial power to initiate action.

According to David Sims (2003), the power of governorates is weakened by the dual executive system, where national ministries have their own sectorial directorates within the governorate through which sectorial budgets flow. In addition to the entities illustrated in its administrative structure (Fig. 2), Giza Governorate encompasses 15 sectoral directorates, which follow their respective national ministries. Each directorate has its own administrative structure (Giza Governorate). For example, in Giza Governorate, the MOE's directorate, the Department of Environmental Affairs Office, directly reports to the Governor (Giza Governorate) as illustrated in Fig. 2. The Department of Environmental Affairs Office is the entity responsible for all environmental issues within the governorate; however, climate change is not one of its responsibilities. Moreover, the department's responsibilities are purely those of administration and coordination (Giza Governorate).

\section{Methodology}

To achieve the research aim, a twofold methodology is used. The first part utilises desk research to investigate enabling factors of urban climate change governance and review the current state of urban climate governance in Egypt, and more specifically in Giza governorate via the GCCS. The second part comprises exploratory semi-structured interviews conducted with a few carefully selected experts working on climate change and urban policies in Egypt to reach a deeper understanding of the case study's context and implementation prospects.

\section{Desk Research}

The desk research consists of two parts. First, a list of urban climate change governance enabling factors was extracted based on the review of relevant literature 
from major urban development organisations (e.g. UN-Habitat) and publications of renowned scholars in the field of urban climate change governance. This list was used to assess the practices of three international case studies of similar circumstances (socio-economic characteristics and/or climatic and governance framework and challenges) to the Egyptian case study based on secondary information. Causal analysis method was used to relate activities, actions, and results to the compiled list of enabling factors. Second, the Giza Climate Change Strategy Framework Document (GCCS) was reviewed (key aspects are presented in the Case Study Section 24), and the refined list of enabling factors was used to assess its approach and context.

\section{Exploratory semi-structured interviews}

The conducted semi-structured interviews are explorative, aiming to understand the current situation, identify the pitfalls and the required actions for urban climate governance in Egypt with a focus on climate change mainstreaming, awareness, legal framework, and governance links. The interviews had 3 focus points, which are (1) understanding the case study context and the state of local governance in Egypt, (2) investigating the process of drafting the GCCS and its implementation prospect, beyond the desk research, and (3) investigating the local relevance and comprehensiveness of the extracted enabling factors. Table 2 outlines the interviews guiding questions. A total of 8 urban climate change experts, who are working or have worked in Egypt on different levels and sectors, were interviewed. Table 3 comprises the interviewees' backgrounds and affiliations. All interviewees had rich backgrounds, with five interviewees working in academia in addition to their professional and practical fields.

The interviews were recorded and accurately transcribed during collection. Both inductive and deductive analysis methods were used. For the general questions, an inductive method was used, where the responses were categorised into themes related to the research question. While for the questions related to the enabling factors, a deductive method was used where responses were utilised to test these factors' relevance to the Egyptian context.

\section{Research Limitations}

The research limitations include the limited number of experts engaged in climate change and specifically urban climate governance in Egypt. Moreover, the local government refrained from engaging in interviews due to the topic's controversy and the lack of climate change mainstreaming. Nonetheless, the interviewees were carefully chosen to represent a diversity of expertise from different related organisations as evident in Table 3. It is worth mentioning that the paper does not discuss the components of the GCCS; rather, it focuses on the factors that enable the implementation of the strategy and its related projects. 
Table 3 Interviewees' background

\begin{tabular}{lll}
\hline Background & $\begin{array}{l}\text { Number of inter- } \\
\text { viewees }\end{array}$ & Affiliation \\
\hline $\begin{array}{l}\text { National government } \\
\text { NGOs }\end{array}$ & 2 & $\begin{array}{l}\text { Climate Change Central Department (CCCD) } \\
\text { under the EEAA, the acting arm of the MOE - } \\
\text { Ministry Advisors }\end{array}$ \\
$\begin{array}{l}\text { International development } \\
\text { organisations }\end{array}$ & 2 & $\begin{array}{l}\text { Union of Egyptian Environmental NGOs } \\
\text { The German Development Agency (GIZ) } \\
\text { Urivate sector }\end{array}$ \\
Urban planning & 1 & Environmental consultancy office \\
\hline
\end{tabular}

\section{Case Study: Giza Governorate, Egypt}

\section{Background}

The formulation of the GCCS was initiated by the MOE, where the Adaptation Department of the EEAA's CCCD collaborated with the then Deputy Governor of Giza to formulate a draft climate change strategy (Interview, 3 June 2019). This draft was further developed in collaboration with the GIZ's Participatory Development Programme in Urban Areas (PDP) to reach the GCCS. A local consultancy office was hired to carry out the research and the document development. The GCCS was officially launched on the 30th of May 2019 (Khalifa, 2019). An interview with the Executive Project Manager of the GCCS has been conducted on Monday the 17th of June 2019, to investigate the document's development process and implementation prospects.

\section{The Giza Climate Change Strategy Framework Document (GCCS)}

The GCCS focuses mainly on adaptation projects through a sectoral approach, where "hotspots" are identified for each sector within the governorate's different areas. In total, 10 categories $^{1}$ were investigated to assess the vulnerability of the different areas, including economic impacts of disaster, natural hazards threat, climate change impacts, political implications of disasters, disaster response system, and governance structure for disaster risk management, among others. Given the governorate's varied nature, the consultancy team divided its areas into 5 categories. These categories are (1) rural, (2) urban areas with rural character, (3) urban, (4) urban desert cities, and (5) oases. The hotspot identification and assessment revealed that all 5 categories are vulnerable with varying degrees, with the 2 nd category being the most vulnerable and the 4th being the least vulnerable. This hotspots approach was chosen so that the governorate could prioritise implementation areas in the case of limited resources (Giza Governorate, 2018).

\footnotetext{
${ }^{1}$ The consultancy team combined the World Bank's and the UNEP's hotspot identification methodology, as well as including Giza-specific themes (Giza Governorate, 2018).
} 
A Steering Team that reflects the strategy's sectoral approach was formed to support the consultancy team. The Steering Team consisted of 12 employees from 9 different governorate sub-divisions. These include the Urban Upgrading Unit, the Road and Transport Directorate, the Crisis and Disaster Unit, the Water and Wastewater Company of Giza, the Tourism Department, the Environmental Affairs Department, the Electricity and Energy Department, the Health Directorate, and the Agriculture Directorate (Giza Governorate, 2018). The Steering Team was capacitated to lead the further development and implementation of the GCCS. According to the project's executive manager, the Steering Team was very effective and most of the generated ideas and projects were based on their input. However, their continuity is not guaranteed unless they are incentivised, and an official decree is released to legalise their role (Interview, 17 June 2019). In addition to the Steering Team's input, consultations were held by the consultancy team with different entities from the governorate and the national level (Giza Governorate, 2018).

Based on the collected data, the consultancy team formulated 5 strategic policies to be adopted by the governorate to combat climate change impacts, as well as programmes to implement these policies. The strategy also identified the expected barriers to the adoption and implementation of the strategic policies and suggested policy tools that could be used to overcome them (Giza Governorate, 2018). Table 4 summarises the barriers and the suggested policy tools. The five strategic policies are as follows (Giza Governorate, 2018):

1. Conserve resources.

2. Preserve the governorate's sources and assets from climate change impacts.

3. Improve infrastructure and services to adapt to climate change.

4. Achieve low-emission development.

5. Protect citizens from the health impacts of climate change.

The programmes included in the GCCS to implement the strategic policies are divided into four levels. These levels are (1) programmes that can be implemented or supervised by the governorate, (2) existing national/local efforts to be followed up/strengthened by the governorate, (3) recommendations from the local level to the national level, and (4) recommendations at the local level. For the first level, 19 programmes for Giza's climate change sensitive sectors were developed, including implementing entities, and expected costs for the pilot phase. A four-level MRV system that is in line with the Egyptian national system has been designed for the GCCS's implementation, where the EEAA's CCCD plays a consultative role. Moreover, the document suggests the use of performance indicators to assess the strategy's progress (Giza Governorate, 2018). 


\section{Urban Climate Change Governance Enabling Factors and the GCCS}

As mentioned in the GCCS document, "the document is intended to form the basis for a more comprehensive climate change strategy for the governorate to be developed in the upcoming years" (Giza Governorate, 2018). This is evident in the document's problem-solving and recommendations-based approach. Moreover, the document suggests changes instead of claiming that changes are being/have been made. This could also be attributed to the fact that a consultancy team has drafted the strategy in collaboration with the governorate instead of governorate employees, for example, from the Environmental Affairs Office Department. The document also claims that the GCCS is an important stage in the integration of climate change into the governorate's project planning (Giza Governorate, 2018). Below is the analysis of the GCCS's approach based on the 16 enabling factors (Table 1).

\section{Governance framework}

While Egypt is a centralised republic, according to the current Minister of Planning Hala el-Said, the government has approved the unified planning law, which is consistent with the state's policies to promote and generalise decentralisation (Egypt Today staff, 2017). However, it will take years for this law to be fully functional. Regarding the GCCS's approach with its five strategic pillars and different recommendations and programmes, the document has a holistic sustainability approach as it takes into consideration resource conservation and efficient use, the country's, and the governorate's political setup, and to an extent culture. The GCCS is mostly in line with Egypt's NAS, which provides a national legal framework through which the governorate can work on adaptation projects. Moreover, the GCCS is supported by the MOE. However, governorates are not mandated to work on climate change since it has not yet been included in the Egyptian Environment Law. Giza Governorate overcomes this barrier through creating synergies and co-benefits between climate action and development needs.

Cooperation and communication between and within all government levels in Egypt in general is relatively low. However, the cooperation between MOE and Giza to develop the GCCS is a positive step. In general, climate change leadership and commitment in Egypt varies and could be rated between weak and moderate. In Giza, the political leadership of the then Deputy Governor has been a strong driver of the GCCS's development. However, it is unclear whether future Deputy Governors will have a similar commitment to continue the GCCS' development and produce a comprehensive long-term climate change strategy for Giza. Although the GCCS recommends the issuance of a governor decree to mandate the strategy and its Steering Team, so far, there has not been any long-term legal or regulatory changes to support political leadership. Moreover, a climate change team/focal point does not exist beyond the unmandated cross-sectoral Steering Team, and a GCCS implementation manager has not yet been assigned.

Most of the programmes mentioned in the GCCS are short-term pilot projects, and the strategy lacks long-term vision and missions beyond the 5 strategic pillars, which are very general. Thus, implementation and continuity could face challenges, 


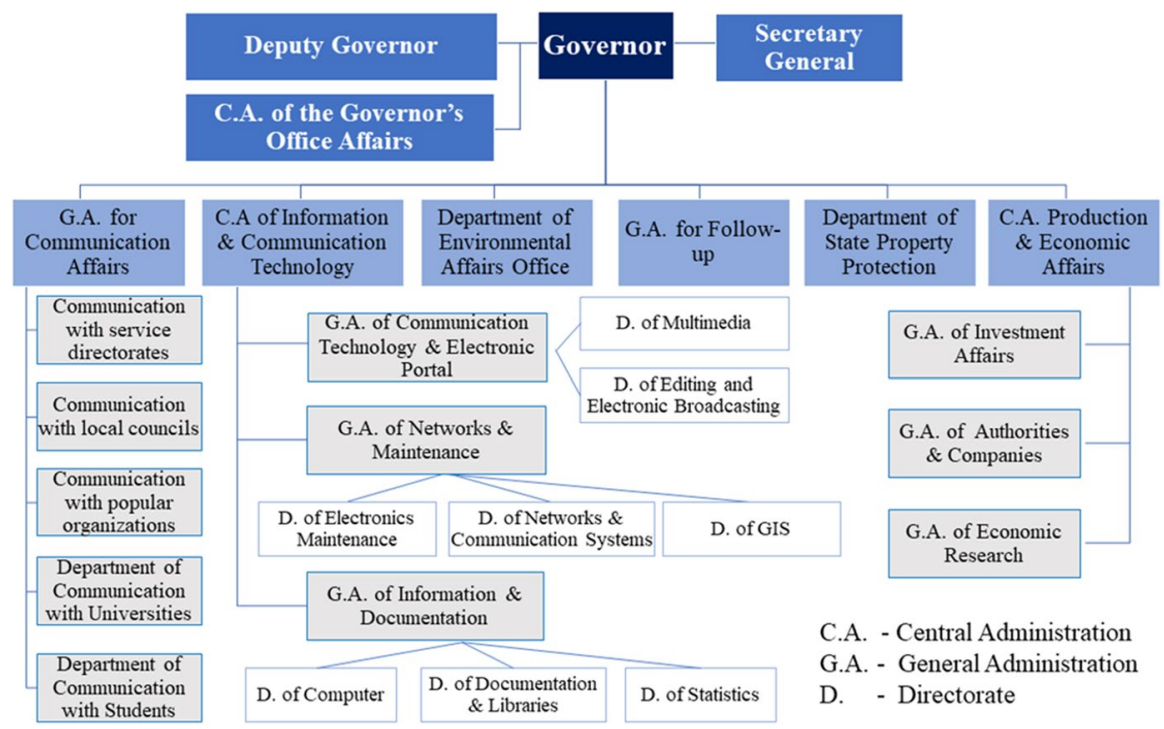

Fig. 2 Giza governorate's administrative structure (Reproduced by author based on data from (Giza Governorate, n.d.))

especially in the case of a governors' reshuffle or employees' relocation. Although the cross-sectoral approach of the GCCS is a step towards mainstreaming, the document does not explicitly mention the mainstreaming of climate change within the governorate's plans and projects.

\section{Resources}

The case of the GCCS exemplifies how national governments and international organisations can provide technical and financial support to local governments. However, this is insufficient, and Giza should seek more opportunities of financial, technical, and technological support. According to the GCCS's executive manager (Interview, 17 June 2019), local capacities and awareness levels in general are low; consequently climate change capacities are low. This is clear through the outsourcing of the GCCS to a consultancy office. Thus, in addition to general capacity development, climate change-related capacity development is also needed.

\section{Inclusive Cooperation}

According to the project's executive manager, the level of inclusiveness within the governorate during the drafting process was very high (90-95\%) (Interview, 17 June 2019). However, cooperation with academia, the private sector, and NGOs started after the GCCS was drafted. Moreover, public participation mechanisms were not employed during the development process. Thus, the next phases of developing a fully-fledged climate change strategy need to be inclusive of all stakeholders during the planning, development, and implementation. 
Table 2 Interviews guiding questions

\begin{tabular}{|c|c|}
\hline Focus point & Questions \\
\hline The Egyptian context & $\begin{array}{l}\text { 1. How would you assess the governance links between national and } \\
\text { local governments regarding planning and urban climate change } \\
\text { adaptation? } \\
\text { 2. Does the action plan currently being drafted to implement the } 2011 \\
\text { adaptation strategy include local-level action or only national-level? } \\
\text { 3. To what extent does the government mainstream climate change } \\
\text { into national plans? } \\
\text { 4. How would adding a climate change chapter to Egypt's Environ- } \\
\text { ment Law support local action on urban climate change? } \\
\text { 5. To what extent does national government support in the awareness } \\
\text { raising of urban communities and institutions on climate change? } \\
\text { 6. In Egypt, how beneficial would it be to view urban climate change } \\
\text { as an opportunity for green economic growth? }\end{array}$ \\
\hline Local governance and the GCCS & $\begin{array}{l}\text { 7. Do governorates conduct in-house planning in Egypt? And from a } \\
\text { planning perspective, how can climate change be mainstreamed in } \\
\text { local government? } \\
\text { 8. How do governorates function, and how would you assess com- } \\
\text { munication networks and coordination? }{ }^{*} \\
\text { 9. What are the barriers to autonomous local action on urban climate } \\
\text { change adaptation? } \\
\text { 10. How would you assess current adaptive capacities on the local } \\
\text { level in Egypt? } \\
\text { 11. Could you briefly describe the GCCS process and the main barri- } \\
\text { ers towards its: (1) drafting and (2) implementation? }{ }^{*}\end{array}$ \\
\hline Enabling factors related & $\begin{array}{l}\text { 12. From your experience, what are the enabling factors of urban } \\
\text { climate change governance on local level? } \\
\text { 13. Kindly assess the importance of the following } 16 \text { factors to the } \\
\text { Egyptian context }\end{array}$ \\
\hline
\end{tabular}

${ }^{*}$ These questions were asked to certain interviewees according to their expertise.

\section{Knowledge}

The hotspots analysis and identification approach of the GCCS shows that a reasonable level of understanding of existing societal vulnerabilities to the possible climate change impacts exists. However, it is lacking a deeper analysis of adaptive capacities and studies on ecosystems. Moreover, the GCCS does not take into consideration socio-economic costs of climate change adaptation. According to the project's executive manager (Interview, 17 June 2019), awareness raising by higher levels of government is minimal and limited to periods of extreme weather events, e.g. heatwaves. In general, climate change information and awareness levels within the governorate and of the citizens need to be raised. 


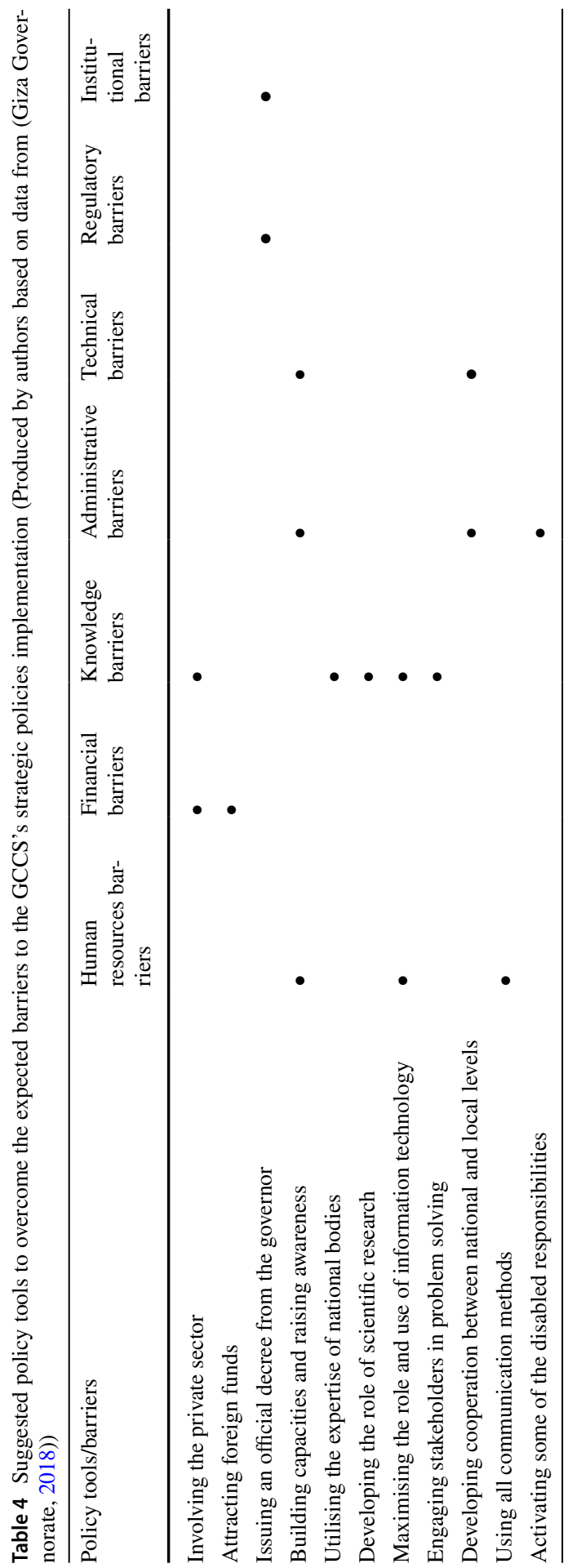




\section{Results of the Semi-structured Interviews}

\section{The Egyptian Context}

\section{Climate Change Mainstreaming and Awareness}

According to the interviewees, the climate change mainstreaming on the national level is currently an ongoing process carried out through the update of Egypt's Sustainable Development Strategy (SDS) Egypt's Vision 2030 and through meetings held by the CCCD with the different ministries. Given that the SDS falls under the Ministry of Planning, it will get mainstreamed into all other ministries' strategies and plans, thus mainstreaming climate change. However, capacitated employees, who understand climate change, are needed within each ministry to support such mainstreaming. An important issue stressed by one of the interviewees is that although mainstreaming might be taking place on the national level, "the local level, which should be the main implementing entity, lacks the needed links to national government in order to mainstream climate change". He further adds that "the workable knowledge needed to integrate climate change into their [local government] plans and projects is missing" (Interview, 13 June 2019). Another interviewee pointed that "if you cover the news, you will hardly read anything related to climate change in Egypt. So, it is also a media issue...it is not mainstreamed into public, and it is not mainstreamed into media" (Interview, 9 July 2019).

An interviewee working on the national level stressed the need for integration across sectors stating that "by trying to achieve the SDGs, we are capturing the climate change issue" adding further that "the major problem in achieving significant progress in achieving the SDGs is the lack of integration across the socio-economic dimensions and across sectors" (Interview, 17 July 2019). He also argued that standalone climate change strategies, whether at the national or the local level, are not the answer stating that "it [climate change] should be part and parcel of the whole so that it gets implemented" (Interview, 17 July 2019).

According to an interviewee affiliated with the EEAA, current awareness raising efforts are "fragmented" with no apparent plan, depending on the availability of funds. However, he further stated that "it is planned to draft a climate change awareness raising plan in the near future" (Interview, 3 June 2019). Upon asking an interviewee working on the national level about the ability of the national government to raise the public's awareness on climate change, he replied in a series of rhetoric questions and answers as follows: "First, do government employees know what environmental issues are and what their implications on the economy are? No, they do not. If I do not understand, how will I apply?". He added further that "the key is once they [government employees] understand the severity of climate change implications and the unsustainable production and consumption patterns, they will take it on board but, they must understand first and be convinced" (Interview, 17 July 2019). Overall, interviewees agreed that more coordinated and periodically repeated awareness raising campaigns with greater outreach are needed. 


\section{Legal Framework and Governance Links for Climate Action}

The Egyptian Environment Law is the general framework of environmental policy in Egypt. An interviewee affiliated with EEAA mentioned that a climate change chapter is currently being drafted to be included in the Law (Interview, 3 June 2019). Upon asking the other interviewees on the usefulness of such a chapter, some interviewees were sceptical referencing the relative weakness of the Egyptian Environment Law. The responses included the following statements: "No, this is not needed" (Interview, 18 June 2019), "[it is useful] to a certain extent but minimal" (Interview, 18 June 2019), "this [chapter] will not support local action since the Law of Localities has been inactive since 2015" (Interview, 22 June 2019), "The question really is how powerful this environmental law really is" (Interview, 9 July 2019). On the other hand, some interviewees find such a chapter a needed step towards establishing a legal framework for climate change action in Egypt on both the national and the local levels. One interviewee's response was, "Of course [It will be useful], ...If the law is written in an easily understandable way and its executive regulations are clear" he further added that "efforts need to be put into capacitating local government employees to know how to apply this in their work, because it is cross-cutting and will not be implemented by one department within the local government but by all" (Interview, 13 June 2019).

Regarding the governance links between the national and the local government levels in Egypt, all interviewees agreed that they are generally weak and unclear, and not only regarding climate action. One of the interviewees explicitly stated that "We do not have a governance system, we have a local administrative system, which is a huge difference" (Interview, 13 June 2019). Another interviewee working on the national level stated that governance links for climate action suffer from fragmentation between all institutions on the different levels, listing the reasons for such fragmentation as follows (Interview, 3 June 2019):

1. The Ministry of Planning's fund allocation plan does not give importance to climate change, or environmental issues and the MOE's funds are very limited given its advisory nature.

2. The responsibilities and contribution of each entity/institution are unspecified, thus hindering coordination and sometimes leading to redundancy of efforts.

3. Given that climate change is a cross-cutting issue, it is unknown which entity should be held accountable. Although the Egyptian Meteorological Authority claims jurisdiction over the issue, its actual contribution is limited to scientific observation and measurements.

Another interviewee identified poor data management as a reason for weak governance links stating that "links between institutes require data management and data management in Egypt is weak if there are no clear benefits". He further added that "links in Egypt are rather weak between national level entities, let alone between national and local level entities" (Interview, 17 June 2019). 


\section{The Local Government Level: Autonomous Action and Adaptive Capacities}

Local capacities and autonomy are closely linked since autonomy requires a high level of capacities. Inadequate financial capacity has been identified by almost all interviewees as the dominant barrier to autonomous action, especially on the local level. An interviewee mentioned that Egyptian governors are very restricted and do not have full control over the governorate's budget, e.g. governors should not move money from one budget line to another (Interview, 18 June 2019). Another interviewee pointed out that some individual competencies of leadership that can form governance coalitions to accomplish a certain goal exist. However, he also mentioned that local government lacks initiative, stating that "they might have a mandate that could be used...but there is no culture that the local level takes initiative" (Interview, 9 July 2019). According to the interviewee affiliated with the EEAA, the absence of a climate change team or focal point within the local government is also a barrier to autonomous climate change action. Other barriers include the lack of knowledge and awareness. Overall, one interviewee summarised the barriers to local autonomous action as "limited mandate, limited capacities and limited resources" (Interview, 9 July 2019).

Regarding the local level adaptive capacities, interviewees agreed that they are generally weak and need strengthening. Among the missing capacities on the local level are long-term planning, project management, and communication skills. According to an interviewee working on the national level, capacity development "is essential and is badly needed" (Interview, 17 July 2019). He also mentioned that the national government has started capacity development programmes in 2017, stating that "now there is a process of developing the capacities of the governmental cadres... and we are trying to integrate sustainability and environmental issues" (Interview, 17 July 2019). He then added that "generally speaking the employees' capacities are weak, let alone environmental aspects" (Interview, 17 July 2019). An interviewee with an urban planning background stated that "[local government] is majorly reactive and [employees] work with what they have to solve the problems they face" (Interview, 18 June 2019).

\section{Urban Climate Governance Enabling Factors in Egypt}

The interviewees were asked to list, based on their experience, the enabling factors for urban climate change governance. Figure 3 illustrates the listed factors. The two most mentioned factors are "capacity development" and "local knowledge and information", which are two closely related issues that Egyptian local governments lack. Moreover, these two points have also been discussed several times for different questions during each interview. The second most mentioned factors are "political will and leadership" and "continuous awareness raising". Political will is viewed as the main driver of action on both national and local levels in Egypt, as an interviewee affiliated with environmental NGOs stated, "nothing will happen without it [political will]" (Interview, 18 June 2019). Another interviewee stated that "political commitment is essential" (Interview, 17 July 2019). 


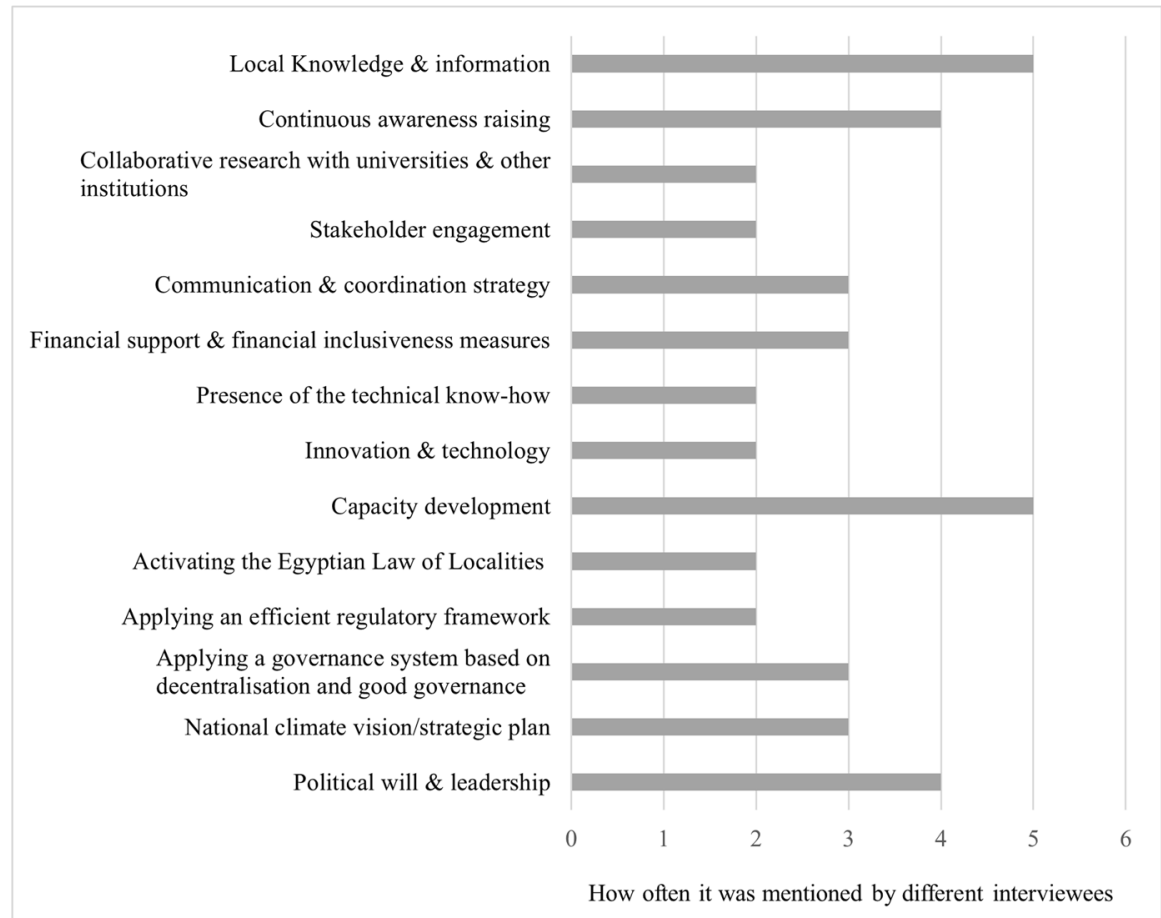

Fig. 3 Governance enabling factors for local climate action mentioned by interviewees

The interviewees were also asked to assess the importance of the 16 enabling factors (Table 1) within the Egyptian context. Overall, there is a consensus on the factors' importance within the Egyptian context, yet they vary in importance. One interviewee pointed out that "all these issues [enabling factors] are complementary [to each other]" (Interview, 17 July 2019).

\section{Discussion}

Climate change is a rapidly intensifying threat that challenges all urban areas. While national-level climate change mainstreaming in Egypt is a work-in-progress, awareness raising initiatives are still rather weak despite the low level of public climate change awareness. The results have shown that awareness raising needs to start with government employees as they first need to understand and be fully aware of the implications of climate change to be able to raise the general public's awareness. Government employees also must become aware of the necessity of data management to enhance governance links between the different levels. Although Egypt might be on the path to decentralisation, it will take considerable time and effort to become a decentralised state, with fully functional multilevel governance. Since climate change is an urgent issue, especially after the IPCC's 2021 report signalling a red alert for humanity, Egypt needs to devise a way for climate action to trickle 
from the national level to the local level that is not constrained by the achievement of decentralisation.

The results of the case study analysis and the interviews have highlighted several issues closely related to urban climate change governance and beyond. First, the issue of multilevel governance and what should be identified as the government's local level for adequate climate change adaptation. In the case study, Giza governorate follows the administrative subdivision of Egypt's government. However, when dealing with climate change actions, the GCCS has highlighted the difference in the nature and hence climate change vulnerability between the governorate's settlements (whether urban, peri-urban, rural, or desert cities). This highlights the importance of considering the local level of action to be the city, especially given that urban areas were identified as the most vulnerable to climate change. Accordingly, the city autonomy should be strengthened, especially the unit responsible for physical planning analysis and action as per the urban planning laws. In parallel, when studying Giza city, it is vital to address that it is part of the GCR. Yet another governance issue arises with the absence of a metropolitan governance structure for the GCR: Egypt's largest metropolitan area and the second largest in Africa. This is clear in the absence of the GCR or even Cairo or Giza in any of the city level coalitions (supra-city level networks) related to climate change action (e.g. ICLEI) reflecting a lack of autonomy or interest to engage from the local level across the globe. Hence, a different approach to identifying local level of urban climate change governance in centralised systems is required for better focused actions. Second, given the complex multifaceted cross-sectoral nature of climate change, it will not be tackled through conventional administrative means and should be perceived as a crosscutting issue that affects and is affected by all urban sectors. Hence, links to other planning tools and processes at the strategic urban planning process as mandated by the unified building law no. 119 is vital. Third, the reactive nature of the local government in Egypt, working with the available capacities to solve problems as they arise, overwhelmed with the day-to-day crisis management, prevents being proactive and having a long-term plan. This reactive approach is problematic as cities need to take adaptive measures before climate change causes severe losses. Consequently, changes in the governance and regulatory frameworks are needed to be able to plan and adapt to climate change, especially in a centralised structure like Egypt. The analysis of the Giza Governorate administrative structure and the GCCS has highlighted that Egyptian governorates need to be given a higher degree of autonomy, especially financial autonomy, to be able to plan and act according to current vulnerabilities and expected risks. Additionally, the GCCS analysis has highlighted that while competent leadership, which can form governance coalitions as a soft measure for better coordinated actions, exists, this does not ensure implementation. On the regulatory level, although some interviewees argue that including climate change in the environment law might not be effective given the law's relative weakness, it is essential in order to provide a legal framework and mandate climate change action for local government leaders.

While Giza Governorate has become the first Egyptian governorate to act on climate change through the GCCS, the document only lays a foundation for a more comprehensive strategy that is yet to be developed. Moreover, funds to implement 
the short-term programmes of the GCCS have not been secured yet. Alternatively, the governorate plans to seek the support of international organisations and the private sector. This accentuates the necessity to link to and capitalise on other ongoing planning and budgeting tools that tackle climate change even if these tools are mandated by the national level and not the local level. The use of the current mainstreaming of Egypt's SDS and the process of achieving and monitoring the SDGs could prove to be helpful in providing a political mandate, as well as the required funds for implementing relevant projects. This could be achieved through involving each Ministry's sectoral directorate within the local government.

As stressed by one interviewee, integration is key to achieving developmental and environmental goals through the SDGs. This perspective is in line with the 2nd overarching enabling factor mentioned earlier in the methodology section, which is "a holistic sustainability approach that takes into consideration ecology, politics, economy and culture". Thus, the implementation of environmental policies in a centralised system like Egypt, whether on the national or the local level, could only be achieved through their mainstreaming into existing government plans, facilitating funding, and implementation. Such a mainstreaming perspective is needed, especially in the context of competing development priorities and limited resources.

\section{Recommendations}

Based on the research results, two sets of recommendations for urban climate change governance in Egypt have been formulated. To build on the previous categorisation of the 16 enabling factors, the four categories have been grouped into two categories, which are Pillar A (Capacities and Resources) and Pillar B (Governance Framework and Inclusive Cooperation) (Fig. 4). While the lack of decentralisation, multilevel governance and autonomy in Egypt poses several challenges for local action, a far more pressing challenge is the lack of knowledge, awareness, resources, and capacities on the subnational, the local, and occasionally on the national level. For this reason, the recommendations of Pillar A should lay the foundation for Pillar B.

In developing countries, where resources and capacities are limited, climate change could be viewed as an opportunity for positive change and development. According to the results of the interviews and the Giza Governorate case study analysis, both the national and the local level governments in Egypt require tremendous, coordinated efforts to tackle climate change. Based on the current governance framework in Egypt, it is recommended that governorates formulate action plans for Egypt's SDS, which mainstreams climate change, rather than formulating standalone climate change strategies. These action plans would ensure that the subnational and the local levels would receive the needed support and resources from the national government. Moreover, for governorates to be able to formulate such action plans, knowledge and capacities of their employees must be raised, and the governorates overall autonomy needs to be enhanced, especially its financial autonomy. The climate change risk could be viewed as an opportunity for governments to raise capacities and awareness and build knowledge and possibly establish a tailored multilevel 


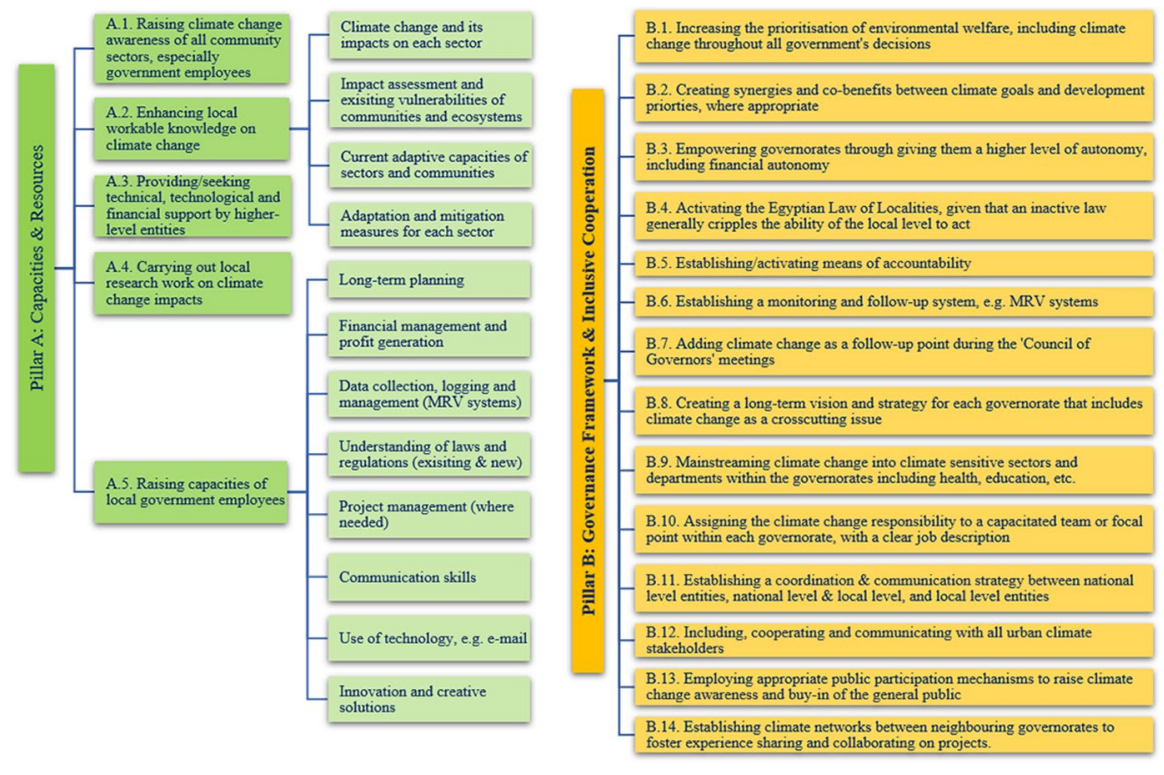

Fig. 4 Recommendations for urban climate change governance in Egypt

governance system for centralised governments. Moreover, it is an opportunity for environmental investments and green economy growth.

\section{Conclusion}

Local governments around the world are the closest level of government to the ground. That is why they are encouraged to proactively build resilience and adapt to climate change. However, local level climate action is strongly affected by a country's governance framework, and a universal governance solution does not exist. Within centralised governance structures, especially in low- and middle-income countries, local governments usually struggle to build resilience due to competing development needs and a lack of capacities and resources. During this Decade of Action (2021-2030), the localisation and implementation of the SDGs and the achievement of a Build Back Better approach post COVID-19 require knowledge building, awareness raising, and capacity development on all levels; higher degrees of freedom and autonomy, especially financial autonomy, within local governments; and the existence of informed leadership and political will to proactively adapt to climate change and build resilience. Given its complex cross-boundary and crosssectoral nature, climate change will not be tackled through conventional administrative means and new multilevel governance frameworks that are tailored to centralised governments need to be devised. Increased collaboration across and between the different levels through local and international city networks (e.g. C40 and the Global Resilient Cities Network) is also needed to fill the gaps in resources and 


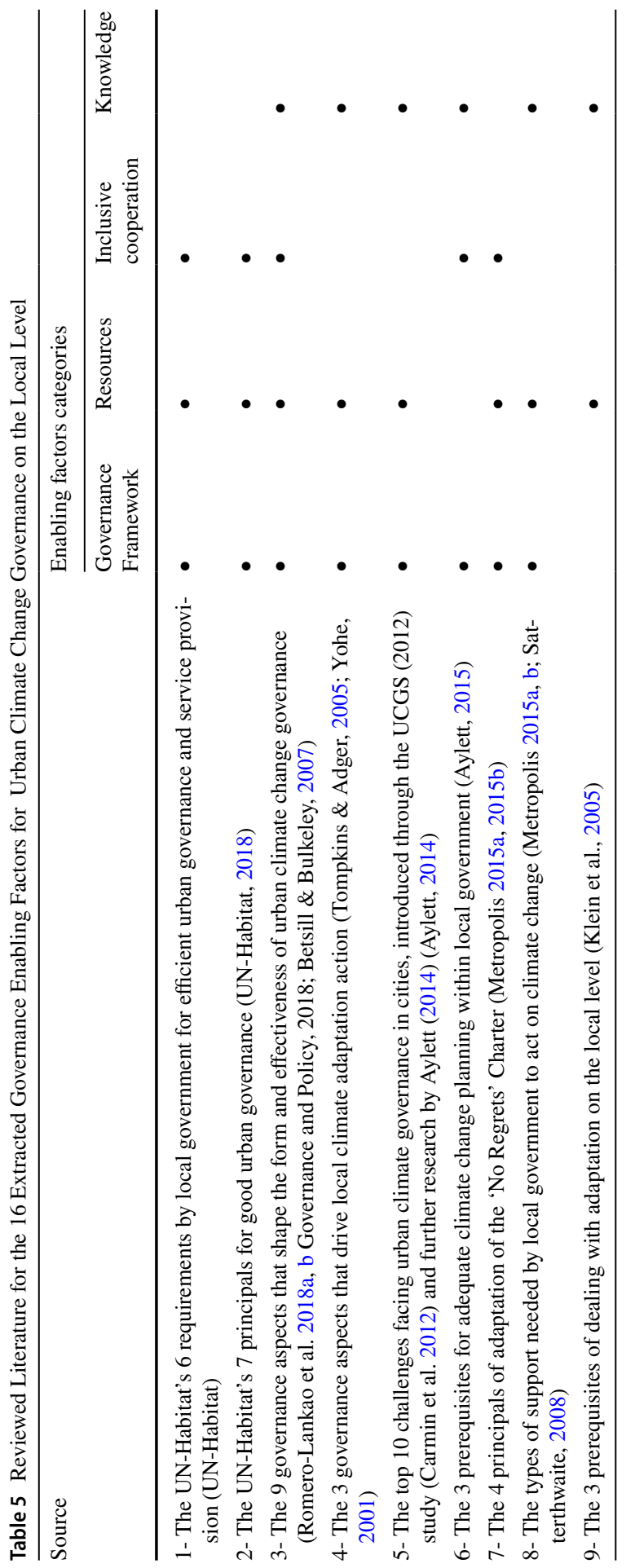


knowledge. In developing countries like Egypt, a unified holistic sustainable development approach that integrates resilience, environmental, and development needs must be adopted by national governments and should trickle down to local governments in the form of implementable action plans. The recommendations in Pillars $\mathrm{A}$ and $\mathrm{B}$, although developed for urban climate change governance, could extend to inform the process of implementing the SDGs in Egypt. They could also be adapted to suit other countries with similar government systems and socio-economic challenges 5 .

\section{Appendix 1}

Acknowledgements The authors would like to thank the Deutsche Gesellschaft für Internationale Zusammenarbeit (GIZ) GmbH, Participatory Development Programme in Urban Areas, for providing initial access to the Giza Climate Change Strategy Framework Document (GCCS). The authors would also like to thank all interviewees for their time and generosity in sharing their experience.

Data Availability Not applicable.

Code Availability Not applicable.

\section{Declarations}

Conflict of Interest The authors declare no competing interests.

\section{References}

Abdulrahman, M. A. (2016). Innovation in the local administration system in Egypt. The American University in Cairo.

Aggarwal, R. M. (2013). Strategic bundling of development policies with adaptation: An examination of Delhi's Climate Change Action Plan. International Journal of Urban and Regional Research, 37(6), 1902-1915.

Al-Zu'bi, M. (2017). Water-energy-food-climate change nexus in the Arab cities: The case of Amman city, Jordan. The University of Calgary.

Anguelovski, I., \& Carmin, J. (2011). Something borrowed, everything new: Innovation and institutionalization in urban climate governance. Current Opinion in Environmental Sustainability, 3(3), 169175. https://doi.org/10.1016/j.cosust.2010.12.017

Aylett, A. (2014). Progress and challenges in the urban governance of climate change: Results of a global survey. MIT Press.

Aylett, A. (2015). Institutionalizing the urban governance of climate change adaptation: Results of an international survey. Urban Climate, 14, 4-16. https://doi.org/10.1016/j.uclim.2015.06.005

Betsill, M., \& Bulkeley, H. (2007). Looking back and thinking ahead: A decade of cities and climate change research. Local Environment, 12(5), 447-456. https://doi.org/10.1080/13549830701659683

Bulkeley, H. (2010). Cities and the governing of climate change. Annual Review of Environment and Resources, 35, 229-253. https://doi.org/10.1146/annurev-environ-072809-101747

Carmin, J., Nadkarni, N., \& Rhie, C. (2012). Progress and challenges in urban climate adaptation planning: Results of a global survey. MIT Press. Retrieved from http://resilient-cities.iclei.org/filea dmin/sites/resilient-cities/files/Resilient_Cities_2012/Urban_Adaptation_Report_23May2012.pdf. Accessed February 2019. 
Chu, E., Anguelovski, I., \& Roberts, D. (2017). Climate adaptation as strategic urbanism: Assessing opportunities and uncertainties for equity and inclusive development in cities. Cities, 60, 378-387.

CIESIN. (n.d.). Online sourcebook on decentralisation and local development. (Columbia University) Retrieved January 16, 2019, from Center for International Earth Science Information Network: http://www.ciesin.org/decentralization/English/General/history_fao.html. Accessed 16 January 2019.

Croese, S., Oloko, M., Simon, D., \& Valencia, S. C. (2021). Bringing the global to the local: The challenges of multi-level governance for global policy implementation in Africa. International Journal of Urban Sustainable Development. https://doi.org/10.1080/19463138.2021.1958335

Egypt Today staff. (2017). Gov’t approves new planning law, opts for decentralization. Egypt Today. Retrieved from https:/www.egypttoday.com/Article/2/38698/Gov\%E2\%80\%99t-approves-newplanning-law-opts-for-decentralization. Accessed 2019.

Environmental Planning \& Climate Protection Department. (2016). Durban Climate Change Brochure. Durban: eThekwini Municipality. Retrieved from http://www.durban.gov.za/City_Services/devel opment_planning_management/environmental_planning_climate_protection/Projects/Documents/ DurbanClimateChangeBrochureEnglish.pdf. Accessed December 2018.

Environmental Planning \& Climate Protection Department and Energy Office. (2014). Durban climate change strategy. Durban: eThekwini Municipality.

eThekwini Municipality. (2017). Durban Resilience Strategy 2017. Durban: eThekwini Municipality.

Giza Governorate. (2018). Towards a climate change strategy in Giza Governorate framework document. Giza Governorate. Retrieved from https://egwuf.files.wordpress.com/2020/01/giza-climate-changestrategy.pdf. Accessed June 2019.

Giza Governorate. (n.d.). Directorates - home page. (Giza Governorate) Retrieved August 23, 2019, from http://www.giza.gov.eg/moderyat/default.aspx

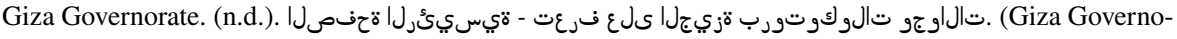
rate) Retrieved August 20, 2019, from http://www.giza.gov.eg/Brotocol/about.aspx

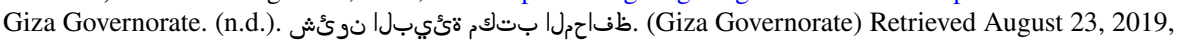
from http://www.giza.gov.eg/Goffice/Affairs.aspx

Giza Governorate. (n.d.). تظفاحمل| تاناي. (Giza Governorate) Retrieved August 23, 2019, from http:// www.giza.gov.eg/HaykalTanzemy/default.aspx

Gordon, D. J. (2018). Global urban climate governance in three and a half parts: Experimentation, coordination, integration (and contestation). WIREs Clim Change. https://doi.org/10.1002/wcc.546

Greater Amman Municipality. (2017). Amman resilience strategy. Greater Amman Municipality.

Greater Amman Municipality. (2019). The Amman climate plan: A vision for 2050 Amman. Amman: Greater Amman Municipality.

Hayward, S. (2019). Decentralisation: Learning from the Jordanian Experience. (The Foreign Policy Centre) Retrieved August 14, 2019, from https://fpc.org.uk/decentralisation-learning-from-the-jorda nian-experience/

Heinrichs, D., Krellenberg, K., \& Fragkias, M. (2013). Urban responses to climate change: Theories and governance practice in cities of the Global South. International Journal of Urban and Regional Research, 37(6), 1865-1878. https://doi.org/10.1111/1468-2427.12031

Hughes, S. (2013). Justice in urban climate change adaptation criteria and application to Delhi. Ecology and Society, 18(4). https://doi.org/10.5751/ES-05929-180448

ICLEI South Asia. (2014). Delhi state action plan on climate change - How it all began... (ICLEI Local Governments for Sustainability) Retrieved April 18, 2019, from http://southasia.iclei.org/newsd etails/article/delhi-state-action-plan-on-climate-change-how-it-all-began.html

IDSC. (2011). Egypt's national strategy for adaptation to climate change and disaster risk reduction. The Egyptian Cabinet.

Johnson, C., Toly, N., \& Schroeder, H. (2015). The urban climate challenge. Abingdon: Routledge.

Khalifa, I. (2019). ثئيبل . Akhbar Elyom. Retrieved from https://akhbarelyom.com/news/newdetails/2859482/1/\%D9\%85\%D8\%AD\% D8\%A7\%D9\%81\%D8\%B8\%D8\%A9-\%D8\%A7\%D9\%84\%D8\%AC\%D9\%8A\%D8\%B2\%D8\%A9\%D8\%AA\%D8\%B7\%D9\%84\%D9\%82-\%D8\%A5\%D8\%B3\%D8\%AA\%D8\%B1\%D8\%A7\%D8\% AA\%D9\%8A\%D8\%AC\%D9\%8A\%D8\%A9-\%D9\%84\%D8\%AA\%D8\%BA\%D9\%8A\%D9\%8A\%D 8\%B1-\%D8\%A7\%D. Accessed September 2019.

Klein, R. J., Schipper, E. F., \& Dessai, S. (2005). Integrating mitigation and adaptation into climate and development policy: Three research questions. Environmental Science \& Policy, 8, 579-588. https:// doi.org/10.1016/j.envsci.2005.06.010 
Leck, H., \& Simon, D. (2018). Local authority responses to climate change in South Africa: The challenges of transboundary governance. Sustainability, 10(7), 2542. https://doi.org/10.3390/su100 72542

Metropolis. (2015a). 'No regrets' charter'. Berlin. Retrieved from https://www.circlesofclimate.org/noregrets-charter. Accessed February 2019.

Metropolis. (2015b). 'No Regrets' Charter'. Berlin.

Ministry of Planning, Monitoring and Administrative Reform. (2018). Egypt's voluntary national review 2018. Ministry of Planning, Monitoring and Administrative Reform.

NAP-GSP. (2018). NAPs in focus: Lessons from Egypt. Retrieved January 26, 2021, from UNDP Climate Change Adaptation: https://www.adaptation-undp.org/sites/default/files/resources/naps_in_focus_ lessons_from_egypt.pdf

Roberts, D. (2018). 3 Climate response planning in Durban. Retrieved August 2, 2019, from Beijing Climate Center: http://bcc.ncc-cma.net/upload/userfiles/3\%20Climate\%20Response\%20Planning\%20 in\%20Durban.pdf

Roberts, D., \& O'Donoghue, S. (2013). Urban environmental challenges and climate change action in Durban. South Africa. Environment and Urbanisation, 25(2), 299-319. https://doi.org/10.1177/ 0956247813500904

Romero-Lankao, P., Burch, S., \& Hughes, S. (2018a). Governance and policy. In C. Rosenzweig, W. Solecki, P. Romero-Lankao, S. Mehrotra, S. Dhakal, \& S. Ibrahim (Eds.), Climate change and cities: Second assessment report of the urban climate change research network (pp. 585-606). Cambridge University Press.

Romero-Lankao, P., Burch, S., Hughes, S., Auty, K., Aylett, A., Krellenberg, K., . . Ziervogel, G. (2018). Governance and policy. In climate change and cities: Second assessment report of the urban climate change research network (pp. 585-606). New York: Cambridge University Press. https://doi.org/10. 1017/9781316563878.023

Rosenzweig, C., Solecki, W., Romero-Lankao, P., Mehrotra, S., Dhakal, S., \& Ali Ibrahim, S. (2018). Climate change and cities: Second assessment report of the urban climate change research network. Cambridge University Press.

Satterthwaite, D. (2008). Climate change and urbanization: Effects and implications for urban governance. Paper prepared for the United Nations expert group meeting on population distribution, urbanization, internal migration and development. UNDESA. Retrieved from https:/www.un.org/ en/development/desa/population/events/pdf/expert/13/P16_Satterthwaite.pdf. Accessed March 2019.

Sheikh, S., \& Banda, S. (2015). The intersection of governments in Delhi. Delhi: Centre for Policy Research. Retrieved from http://www.cprindia.org/research/reports/intersection-governments-delhi. Accessed 2019.

Sims, D. (2003). The case of Cairo, Egypt. In UN-Habitat Global Report on Human Settlements: The Challenges of Slums. Earthscan.

Soni, P. (2014). State action plans on climate change (SAPCCs). Retrieved May 19, 2019, from https:// www.slideshare.net/indiawaterportal/state-action-plans-on-climate-changepreeti-soni-undp15-octob er-2014

Sutcliffe, M., \& Bannister, S. (2015). Case study: Metropolitan governance eThekwini (Durban), South Africa. UN-Habitat.

Tadamun. (2013). The right to democratic local government in the Egyptian constitution. (Tadamun) Retrieved January 20, 2019, from http://www.tadamun.co/2013/12/05/the-right-to-democraticlocal-government/?lang=en\#.XD8U1VwzZPY

Tompkins, E. L., \& Adger, N. (2005). Defining response capacity to enhance climate change policy. Environmental Science and Policy, 8(6), 562-571. https://doi.org/10.1016/j.envsci.2005.06.012

Tu, Y. (2018). Urban debates for climate change after the Kyoto Protocol. Urban Studies, 55(1), 3-18. https://doi.org/10.1177/0042098017717363

UNDESA. (2004). Arab Republic of Egypt- Public administration country profile. United Nations Department of Economic and Social Affairs. United Nations.

UN-HABITAT (2016). Egypt's Housing Profile. UNhabitat

UN-Habitat. (2017). Climate Change - UN-Habitat. Retrieved February 24, 2018, from Unhabitat: https://unhabitat.org/urban-themes/climate-change/

UN-Habitat. (2018). UN-Habitat: Global campaign on urban governance I principles. Retrieved 2019, from http://mirror.unhabitat.org/content.asp?typeid=19\&catid=25\&cid=2097. Accessed March 2019. 
UN-Habitat. (n.d.). Governance - UN-Habitat. Retrieved February 2020, from UN-Habitat - United Nations Human Settlements Programme: https://oldweb.unhabitat.org/governance/. Accessed 2019.

van der Heijden, J. (2017). Innovations in urban climate governance: Voluntary programs for low carbon buildings and cities. Cambridge University Press.

van der Heijden, J. (2018). From leaders to majority: A frontrunner paradox in built-environment climate governance experimentation? Journal of Environmental Planning and Management, 61(8), 1383-1401.

van der Heijden, J. (2019). Studying urban climate governance: Where to begin, what to look for, and how to make a meaningful contribution to scholarship and practice. Earth System Governance. https://doi.org/10.1016/j.esg.2019.100005

van der Heijden, J., Patterson, J., Juholae, S., \& Wolframf, M. (2019). Special section: Advancing the role of cities in climate governance - Promise, limits, politics. Journal of Environmental Planning and Management, 62(3), 365-373. https://doi.org/10.1080/09640568.2018.1513832

Yohe, G. (2001). Mitigative capacity: The mirror image of adaptative capacity on the emission side. Climate Change, 49(3), 247-262.

Publisher's Note Springer Nature remains neutral with regard to jurisdictional claims in published maps and institutional affiliations. 